\title{
Foreign investment and international plant configuration : whither the product cycle?
}

Citation for published version (APA):

Belderbos, R. A. (2000). Foreign investment and international plant configuration : whither the product cycle? NIBOR, Netherlands Institute of Business Organization and Strategy Research. NIBOR Research Memorandum No. 03 https://doi.org/10.26481/umanib.2000003

Document status and date:

Published: 01/01/2000

DOI:

10.26481/umanib.2000003

Document Version:

Publisher's PDF, also known as Version of record

\section{Please check the document version of this publication:}

- A submitted manuscript is the version of the article upon submission and before peer-review. There can be important differences between the submitted version and the official published version of record.

People interested in the research are advised to contact the author for the final version of the publication, or visit the DOI to the publisher's website.

- The final author version and the galley proof are versions of the publication after peer review.

- The final published version features the final layout of the paper including the volume, issue and page numbers.

Link to publication

\footnotetext{
General rights Owners
rights.

- You may freely distribute the URL identifying the publication in the public portal. please follow below link for the End User Agreement:

www.umlib.nl/taverne-license

Take down policy

If you believe that this document breaches copyright please contact us at:

repository@maastrichtuniversity.nl

providing details and we will investigate your claim.
}

Copyright and moral rights for the publications made accessible in the public portal are retained by the authors and/or other copyright owners and it is a condition of accessing publications that users recognise and abide by the legal requirements associated with these

- Users may download and print one copy of any publication from the public portal for the purpose of private study or research.

- You may not further distribute the material or use it for any profit-making activity or commercial gain

If the publication is distributed under the terms of Article $25 \mathrm{fa}$ of the Dutch Copyright Act, indicated by the "Taverne" license above, 


\title{
Foreign Investment and International Plant Configuration: Whither the Product Cycle?
}

\author{
NIBOR Research Memorandum RM/00/03
}

\author{
René Belderbos \\ Maastricht University
}

Leo Sleuwaegen

Catholic University Leuven and Erasmus University Rotterdam

\author{
René Belderbos \\ Faculty of Economics and Business Administration \\ Maastricht University \\ PO BOX 616, 6200 MD Maastricht, The Netherlands \\ Email: r.belderbos@mw.unimaas.nl \\ Internet: http://www.belderbos.net \\ Phone: + 3143388 3445; Fax: + 31433254877 \\ Leo Sleuwaegen \\ Department of Applied Economics \\ Catholic University of Leuven \\ Naamsestraat 69, B-3000 Leuven, Belgium \\ Email: leo.sleuwaegen@econ.kuleuven.ac.be \\ Phone: + 3216 326913; Fax: + 3216326732
}

\section{Acknowledgements}

René Belderbos' research is funded by a fellowship from the Royal Netherlands Academy of Arts and Sciences. Leo Sleuwaegen gratefully acknowledges financial support of the Belgian DWTC (project SE/01/003) and KU Leuven (project OT/96/03). The paper benefited from helpful comments by Reinhilde Veugelers, Thierry Mayer, and participants at seminars at the Université Paris I (Sorbonne) and at Maastricht University. 


\title{
Foreign Investment and International Plant Configuration: Whither the Product Cycle?
}

\begin{abstract}
We analyze the determinants of the decision to invest abroad in particular configurations of overseas plants for 120 Japanese firms active in 36 well-defined electronic product markets. We find support for a structured internationalization decision model in which the decision to produce abroad and the choice for a specific international plant configuration are treated as nested strategic options. Drivers at the industry and firm level push firms to consider overseas investment, and locational characteristics pull firms towards particular plant configurations. The product cycle still appears as an important force pushing firms to set up Asia-focused or global plant configurations. In contrast, plant configurations focused on the US and the EU are a result of restrictive trade policies or offensive market access considerations vital to technology intensive firms facing competitive threats in foreign markets.
\end{abstract}

Keywords: Foreign Investment, Product Cycle, Plant Location, Multinational Firms 


\section{INTRODUCTION}

Since the mid-1980s it has been argued that the increasingly global character of competition in industries is pushing multinational firms to configure and coordinate manufacturing activities on a global basis. Leading scholars such as Porter (1986), Ohmae (1985), and Bartlett and Ghoshal (1987) saw an emerging trend towards networks of decentralized but interdependent plants. Decentralization was seen as a necessity because of strong swings in exchange rates, rising protectionism and a growing need to respond quickly to changing and differentiated consumer demands. Global coordination was to allow firms to benefit from major scale and scope economies associated with shortened product cycles and increasing development costs. A presence in major markets reduces the lag between the introduction of new and improved products between the home and foreign markets, necessary to increase revenues within a shorter time frame. A number of these arguments have also been analyzed formally in more recent work. Kogut and Kulatilaka (1994) show that real option theory can put a value on the operational flexibility gained through operating a global manufacturing network with establishments in different currency areas. Kalish et al. (1995) develop a diffusion model of international product introduction decisions to analyze under which circumstances a 'sprinkler' strategy, which involves the simultaneous introduction of the product in various markets, is preferred over a 'waterfall' strategy of lagged introduction in distant markets. They find that a 'sprinkler' strategy is more likely to be preferred in case of short product cycles, large and growing foreign markets, and strong foreign competition.

These theories and concepts contrast markedly with the traditional product cycle concept of internationalization of production developed by Vernon $(1966,1979)$. Product cycle theory predicts that new products are first introduced and produced in the home market in a 'waterfall' fashion. Foreign investment in overseas production follows with a lag, when process and product technologies have been established and matured and when reduced margins due to increased competition push firms to search for low-cost locations. It has been argued that the developments in the global industry environment from the second half of the 1980s have made the product cycle irrelevant (e.g. MacCormack et al. 1997; Bell 1995, McDougall et al., 1994). However, to date this critique has not been accompanied by systematic empirical tests whether the product cycle has indeed lost its power in explaining 
foreign investment decisions. ${ }^{1}$ This is surprising because the international plant configuration chosen by a firm is a key factor in its internationalization strategy with important repercussions for performance (e.g. Porter, 1986; Morrison and Roth, 1992; Yip, 1995).

In this paper we contribute a systematic empirical analysis of the role of the product cycle in the determination of global manufacturing investment. We adopt a theoretical framework in which the product cycle model is embedded in a more general conceptual model that encompasses other relevant theoretical approaches to foreign direct investment, including internalization theory, resource based theory and the theory of oligopolistic reaction. Empirically, we analyze the decisions to invest abroad and the choice for global or regionally focused international plant configurations by 120 Japanese firms active in 36 well-defined product markets. We constructed a disaggregated database with detailed data on plant locations, market shares, product maturity, and regional market size, among others. This disaggregated level of analysis ensures that we model investment and plant configuration decisions where they are taken: at the business unit level. It enables us to test simultaneously for the effect of product maturity, firm-level competitiveness and product-level competition, and region- and product-specific characteristics such as protectionism and market size. The focus on Japanese industry is of interest since Japanese firms' export strategies in the 1970s and early 1980s made them a specific target of protectionist policies in the US and Europe. This coupled with their 'focus' strategies on serving various developed markets with relatively undifferentiated but high quality products made them early adopters of global manufacturing strategies (Ohmae, 1985; Bartlett and Ghoshal, 2000). At the same time, however, it has been argued that patterns of Japanese foreign direct investment patterns closely follow product cycle theory (Ozawa, 1991; Thomsen, 1993).

Our disaggregated analysis at the firm, product and regional level extends earlier work on (Japanese) foreign investments that has analyzed investment behavior either across industries or across firms (e.g. Belderbos and Sleuwaegen, 1996; Kogut and Chang, 1991; Drake and Caves, 1991), or has focused attention on investments in the US (e.g. Hennart and Park, 1994; Kogut and Chang, 1996; Chang, 1995; Pugel et al., 1996). It shares features of previous studies of plant location decisions (e.g. Mayer and Muchielli, 1999; Head, Ries and Swenson,

\footnotetext{
${ }^{1}$ The evidence to date has consisted of cases studies or descriptive tests of consistency with trade and foreign investment data (e.g. Dubois et al 1993; Ozawa, 1991).
} 
1995; Devereux and Griffith, 1998; Belderbos and Carree, 2000) but broadens the scope of analysis from location decisions for plants within a given country or region to decisions on plant configurations at a global level.

The remainder of this paper is organized as follows. The next section describes the theoretical framework of the model of foreign investment and international plant configuration decisions. Section 3 develops hypotheses concerning the main factors driving these decisions. Section 4 describes the empirical methodology and the dataset. Empirical results are presented in Section 5 and Section 6 discusses the findings and offers concluding remarks.

\section{FOREIGN INVESTMENT AND INTERNATIONAL PLANT CONFIGURATION: A STRUCTURAL DECISION MODEL}

The product cycle model was originally presented as a comprehensive model of interacting factors leading firms to invest abroad, linking the internationalization process to the process of innovation and successful introduction of new products. Initial production takes place near the point of innovation because of communication costs within the innovating enterprise and uncertainty about the production process in early stage market development (Vernon, 1966; 1974). Following diffusion and standardization of the product in the domestic market, firms are driven to exploit foreign markets. Firms typically start by exporting to developed foreign markets, followed by the establishment of plants as those markets reach a critical size, and finally the relocation of production of the mature product in low-cost countries as price competition intensifies. More recent studies (Martin and Salomon, 2000; Kogut and Zander 1993), following pioneering work by (Teece, 1977), have shown that the transfer of technological and organizational knowledge is facilitated by a reduced tacitness and complexity as the technology matures, reducing the cost of the transfer.

A major criticism of the product cycle model has been that the generic and complex process it describes does not provide a solid basis for a theoretical model, since discriminating hypotheses and falsification criteria cannot easily be specified (Anderson, 1994). A related problem is that the model overlaps with a number of other theoretical approaches to foreign investment by multinational firms. For instance, the role of innovative capabilities leading to the introduction of new products driving the foreign investment process is a key element in 
internalization theory (e.g. Buckley and Casson, 1976; Hennart, 1982; Caves, 1996) and the resource based theory of the firm (e.g. Collis 1991; Chang, 1995). Foreign market size similarly features as a major determinant of foreign investment in the internalization literature (Buckley and Casson, 1976; Smith, 1987; Motta, 1992), and the role of competitive pressures in the industry is a driver of foreign investment according to Knickerbocker's (1973) theory of oligopolistic rivalry and foreign investment. However, one prediction of product cycle theory that does complement other theories of foreign investment and allows for an empirical test is the role of product maturity in the propensity to invest abroad and the sequence of geographic destinations of such investments. The model predicts that as the product and its technology mature, firms are more likely to invest abroad and more likely to locate plants in developing countries with lower manufacturing costs. It is this key relationship of product cycle theory that we embed into a more general conceptual model that draws on other theoretical approaches including internalization theory, resource based theory, oligopolistic reaction theory as well as the stage theory of internationalization (Johanson and Vahlne, 1977, 1990). Essentially, we consider the decision to internationalize and choose for a particular spatial configuration of production the result of a decision making process responding to various internal and external push and pull factors (Root, 1987; Anderson, 1994; Yip, 1995; Bartlett and Ghoshal, 2000). Drivers related to firm resources and competitiveness, domestic rivalry, and the product cycle push firms to expand abroad, while a set of locational factors pull firms to invest in specific foreign markets.

The resource-based theory of the multinational firm emphasizes the application of underutilized productive resources to new business opportunities abroad. Intangible resources, such as technology and marketing skills, which can be exploited without substantial extra costs in new markets, encourage firms to diversify into new businesses abroad (Caves, 1971; Wolf, 1977; Chang, 1995; Delios and Beamish, 1999). Successful deployment of resources abroad is based on a strong international competitive position for the products concerned (Chang, 1995). Internalization theory defines foreign investment as the internalization of the market for (technological) knowledge or other intangible assets, driven by high transaction cost associated with the sale or rent of such assets (e.g. Hennart, 1982). In the evolutionary view of the multinational firm it is the relative efficiency of the firm in transferring and exploiting proprietary know how in diverse markets that explains successful multinational investment (Kogut and Zander, 1993). The stage theory of internationalization suggests a sequential pattern in the process of internationalization but emphasizes the role of 
knowledge about foreign markets in determining the direction of internationalization and the commitments firms make in foreign markets (Johanson and Wiedersheim-Paul, 1975; Johanson and Vahlne, 1977; 1990; Fina and Rugman, 1996). Knowledge of foreign markets obtained through exporting facilitates subsequent production abroad, while experience with the process of transferring manufacturing activities abroad reduces the risk and costs of subsequent foreign investments. The role of exporting and overseas manufacturing experience in facilitating foreign investments has been supported by a number of empirical studies (e.g. Davidson, 1980; Chang, 1995; Belderbos 1997a; Martin and Salomon, 2000). According to the theory of oligopolistic rivalry in foreign investment developed and tested by Knickerbocker (1973), the industry environment in the home country may constitute an external push factor for foreign investment. Firms in loose-knit oligopolies follow their rivals in making matching investments overseas to prevent rivals from building up competitive advantages from their foreign presence (e.g. Yu and Ito 1988). Such rivalry may lead to an earlier pattern of substantive overseas investments than product cycle theory would suggest.

The different theories of internationalization imply that the decision to invest abroad depends on the competitive resources of the firm and its international experience and respond to the particular industry environment, in particular the degree of rivalry and the stage of the product cycle. These are firm- and industry-specific factors pushing firms to consider foreign investment. Given the forces pushing firms to decide to establish foreign manufacturing operations, the firm has to decide on a specific plant configuration. This decision is affected by a number of external pull factors favoring specific plant configurations. The main factors distinguished in the literature on (the location of) foreign direct investment are advantages of lower labor cost, the advantages of locating close to a large market, and the need to overcome trade barriers. The importance of being located close to demand is demonstrated by Krugman (1991). Empirically, evidence of the role of local demand and lower labor cost is found in empirical studies of the location decisions by Japanese firms (Head, Ries and Swenson, 1995; Mayer and Muchielli, 1999; Belderbos and Carree, 2000), among others. The pull effect of tariff and non-tariff barriers (such as voluntary export restraints and antidumping duties) on inward investment in particular regions has been theoretically analyzed in Smith (1987) and Motta (1992) and empirically demonstrated in Belderbos (1997a) and Pain and Barrell (1999). Besides these locational pull factors, the choice for particular plant configurations is also affected by firm- and industry factors such as heterogeneities in resources, experience, competitive position and product maturity (Collis, 1991; Yip 1995; Dubois et al., 1993). For 
instance, the firm's possession of market-specific knowledge of a certain region or country favors plant location there (Johanson and Vahlne, 1977, 1990). Firm-specific resources based on technological knowledge are less of a prerequisite to compete in developing countries than in developed markets (Fukao et al., 1994; Belderbos and Sleuwaegen, 1996). Conversely, product maturity and standardization of technologies are more important for the costeffective transfer of production to developing countries (Vernon, 1974).

Given the complexity of the internationalization and plant configuration decision as described above, a test of the role of the product cycle model requires the formulation of hypotheses that can be falsified (Anderson, 1994). In our research design we implement this by introducing a direct measure of the product cycle effect in terms of the maturity of the products. We test whether the standardization and maturity of technology associated with the stage of the product cycle has an impact on foreign investment, independent from factors such as firm-level resources, the attractiveness of foreign markets, and the intensity of competition. In addition, in order to analyze both the decision to invest abroad and the decision to set up different overseas plant configurations, we require an analytical framework that explicitly considers the different working of push factors on the decision to invest abroad as well as the location- (configuration-) specific effects of pull factors. This suggests a distinction between the decision to invest abroad and the plant configuration decision while taking into account that these decisions are taken simultaneously rather than consecutively. An approach that fits these requirements is to treat the decision to invest abroad and the international plant configuration decision as a nested set of strategic options available to the firm. In deciding whether to invest in international manufacturing operations, the firms takes into account the various plant configuration options if foreign investment is chosen and the relative profitability of these configurations. The corresponding empirical model is the nested logit model, in which the potential profitability of different plant configurations features as an independent explanatory variable in the internationalization decision. The nested strategic option model is depicted in Figure $1 .^{2}$ Firm- and industry specific push variables determine the internationalization decision. Locational pull variables determine the plant configuration decision, but these choices are also affected by differential firm- and industry characteristics.

\footnotetext{
2 A similar specification has been used in a plant location model for Japanese firms in the European Union distinguishing countries and regions (Mayer and Ries, 1998) and to analyze the export vs. foreign investment decision and the investment location decisions of US firms (Devereux and Griffith, 1999). The model has the advantage that it can be falsified, i.c. it can be tested whether the distinction between internationalization and plant configuration decisions is a valid one (see section 4$)$.
} 
The attractiveness of the different plant configurations in turn enters the internationalization decision and has an independent positive impact on the decision to invest abroad.

\section{INSERT FIGURE 1}

In the model we distinguish three possible international plant configurations for each product:

- Asia-bound configuration (I): Foreign manufacturing investment in Asia only;

- West-bound configuration (II): Foreign manufacturing investment in the US and/or the EU but not in Asia;

- Global configuration (III): foreign manufacturing investment in all regions.

Hence, we distinguish between investments in the two main developed markets (the US and the EU), investments in developing and newly industrialized countries attracting a major share of Japanese investments (Asia) and investments in both areas. We adopted this structure in order to test the prediction of product cycle theory that product maturity has a differential impact on investments in developed vs. developing countries. In addition, previous research has shown major differences in the relationship between technological and marketing capabilities of firms and investment decisions between Asia on the one hand, and Western markets on the other (Belderbos and Sleuwaegen, 1996). In contrast, earlier studies have shown that Japanese firms' investment behavior is comparable in the EU and the US (Belderbos, 1997a; Barrel and Pain, 1999). We investigated this in the context of our empirical model by considering investments in the EU, US, and investments in both the EU and US as separate configurations instead of configuration II, but found the determinants of these configuration choices to be similar. In order to focus on the main differences between configurations and to keep the number of estimated coefficients manageable, we treat the EU and the US as one developed region. ${ }^{3}$

Table 1 shows the distribution of foreign investment and plant configuration decisions across products for our sample of 36 products. The number of Japanese manufacturers per product

\footnotetext{
${ }^{3}$ Separating the EU and the US out of the global and West-bound configurations would introduce 6 additional configurations and increase the number of coefficients by 102. Aggregating EU and US investment does not imply that we do not incorporate the different locational characteristics of the US and the EU, but rather that we aggregate over such locational factors, assuming that the form of the investment relationship is the same for the two regions.
} 
varies between 6 and 27 and the total number of firm-product combinations is 533. In about half of these cases firms are engaged in foreign investment. Among the different plant configurations, the global and Asia-bound configurations are most common (96 and 93 cases respectively), but the West-bound configuration is also well represented (84 cases). The table shows systematic differences across products (e.g. with a global configuration dominant in the VTR, CTV, and fax industries) but at the same time instances of substantial variation across firms within an industry (e.g. in the CD player and dot matrix printer industries). Below we develop and test hypotheses concerning the determinants of these differences across product markets and firms.

\section{INSERT TABLE 1}

\section{HYPOTHESES}

In the empirical model we distinguish between hypotheses concerning firm and industry push factors driving the foreign investment decision (section 3.1) and hypotheses concerning specific pull factors specific to particular plant configurations (section 3.2). Firm and industry characteristics determine the foreign investment decision and may also exert a differential impact on the probability that a specific plant configuration is chosen. Section 3.3. discusses the use of control variables.

\subsection{Firm and Industry Push Factors}

\section{The Product Cycle}

As argued in the previous Section, Vernon's $(1966,1979)$ product cycle theory suggests that production technologies are more easily transferred abroad and adapted to local conditions, and foreign locations are more likely to have cost advantages, if technologies and products are mature and relatively standardized. For new products, manufacturing will be more centralized because the fast rate of change in product and process technology requires close coordination with $\mathrm{R} \& \mathrm{D}$ operations and an experienced manufacturing work force. Both are most likely to be available in the home country where the firm is headquartered and where strategic decisions are taken. 
Hypothesis 1: Foreign investment is more likely for products that have reached a more advanced stage of their product cycle.

The product cycle also has an impact on the choice of international plant configuration. Investments in less developed countries are likely in the more mature stages of the product cycle, while investments in developed markets are predicted to occur in intermediate stages. In the most mature stages of the product cycle, products are more likely to have been diffused and accepted in less developed countries, and the maturity of the technology makes it more readily transferable in a cost effective way to countries with a less developed technological infrastructure and a less skilled workforce (Vernon, 1974; Dicken, 1998). As a product matures, it is therefore less likely that a purely West-bound configuration is chosen and more likely that a firm also invests in Asia (a global configuration). Concentration of production in low-cost locations in Asia is expected to occur in the most mature stages of the product cycle.

Hypothesis 1: The more advanced the stage of the product cycle, the less likely it is that a West-bound configuration and, to a lesser extent, a global configuration is chosen, and the more likely it is that an Asia-bound configuration is chosen.

\section{Firm competitiveness at the product level and positioning in the home market}

The theory of the multinational firm suggests that only firms with a competitive advantage based on proprietary assets such as technological strength, brand names, or manufacturing expertise will be able to invest abroad and compete successfully (e.g. Caves, 1996; Dunning, 1993). In order to reduce market transaction costs, the coordination of activities related to the exploitation or generation of the proprietary assets are internalized within the firm through foreign direct investments (Hennart, 1982). Mitchell et al. (1992) found firms' competitiveness in a specific product market to be closely related to its domestic market share. Caves (1996: p.58) suggests that the propensity to invest abroad rises monotonously with domestic market share. With higher market shares, further domestic sales increases are more likely to force a competitive response by rival firms, reducing the perceived price elasticity in the domestic market. This reduces the marginal return on domestic expansion relative to the marginal return on expansion to serve overseas markets and encourages foreign investment. Similarly, Chang (1995) finds that Japanese firms are more likely to engage in foreign investment for product lines in which they possess the strongest competitive 
advantage and face the lowest risk of overseas business failure. These investments also have an option value as they can later serve as a platform to expand investment into the firms' less competitive product lines.

Hypothesis 2: The higher a firm's share in the product market in Japan, the more likely that the firm will manufacture the product abroad.

On the other hand, previous studies on foreign investment and export decisions have suggested that domestic market leaders are less likely to expand abroad compared with 'follower' firms with intermediate market shares (e.g. Mascarenhas, 1986; Ito and Pucik, 1993; Hennart and Park, 1994). Given a dominant presence of the market leader(s), follower firms face the strongest constraints on domestic expansion and can only reach a larger scale of operations in case they look for expansion abroad in markets with similar demand characteristics. The empirical evidence has suggested that intermediate positions in the domestic market are associated most strongly with foreign investment in other developed markets. In the context of plant configuration decisions, it follows that this pattern of nondominant firm expansion abroad is most likely to hold in case of expansion in the developed markets of the EU and the US (a West-bound configuration). Given the more limited resources and scale of non-dominant firms, such firms are likely to choose a focused geographic expansion strategy. Investments in developed markets with similar demand characteristics provide the largest marginal benefit and may in addition allow acquisition and development of additional resources (e.g. through takeovers). Dominant firms on the other hand, have the resources and comptitiveness to expand in all regions and to benefit from the scale economies of a global plant configuration. The least competitive firms with the smallest market shares in the domestic market may lack the resources to invest in developed markets and opt for a purely cost-based internationalization strategy focused on Asia.

Hypothesis 2a: Domestic market share has a positive effect on the choice for a global plant configuration as opposed to an Asia-bound configuration. Non-dominant firms are most likely to choose a West-bound configuration.

\section{Oligopolistic rivalry in the domestic market}

The relationship between foreign investment and domestic industry-wide competition has been the subject of research since the seminal work of Knickerbocker (1973). Knickerbocker 
tested the hypothesis that in loose-knit oligopolies firms recognize interdependencies with their oligopolistic rivals and follow these firms as soon as they expand abroad in order to avoid a potential weakening competitive position in foreign as well as domestic markets. In contrast, in tight oligopolies characterized by the highest concentration rates, firms are more likely to invest abroad in a coordinated way that helps to sustain the collusive equilibrium from which they benefit. The hypothesis that in loose oligopolies, rivalry between the firms increases the occurrence and speed of foreign expansion has been supported by various empirical studies (Knickerbocker, 1973; Flowers, 1976; Caves et al. 1980; Yu and Ito, 1988, Chang, 1995; Kinoshita and Mody, 1997).

Hypothesis 3. Firms in loose-knit oligopolistic product markets are more likely to invest abroad.

\section{Industry level competitiveness and the intensity of competition in foreign markets}

Market share in Japan is not necessarily a good indicator of competitiveness vis-à-vis foreign firms, given the differences in the competitiveness of the Japanese industry as a whole vis-àvis foreign firms in the different product markets. We measure the global competitiveness of Japanese industry by the world market share of Japanese firms. Internalization theory of the multinational firm suggests that foreign direct investment is more prevalent by industries possessing more valuable intangible assets and greater global competitiveness (e.g. Hennart, 1982; Dunning, 1983). Firms in leading industries are more likely to be able to overcome the disadvantage of doing business abroad in an unfamiliar environment (Caves, 1996). The greater the industry's world market share, the greater it's overseas market penetration and the more likely that scale economies warrant overseas production.

Hypothesis 4: The greater the global competitiveness of Japanese industry, the more likely it is that Japanese firms operating in this industry invest abroad.

Following the argument concerning firm-level competitiveness, competitiveness at the industry level leading to greater market penetration at the world level is also more likely to enable investments in global plant configurations, and makes it less likely that Asia-bound configurations are chosen. On the other hand, dominance of the world industry is not necessarily a positive force for West-bound configurations. Caves (1996), Kalish et al. (1995) and Motta (1992) have shown that firms can engage in defensive investments abroad in order 
to maintain market share in case of a credible threat of entry by foreign firms in overseas markets. Foreign investment may serve as a strategic commitment to increase market presence and dislodge efforts by foreign competitors to penetrate the market. It may also facilitate adaptation of products to local consumer demand, increased brand recognition and goodwill among foreign consumers, and enable quicker responses to actions of local competitors. These considerations play the largest role in the US and the EU where rival firms pose the strongest threats and where the largest markets are at stake. It follows that investments in the developed markets of the EU and the US are more likely in product markets in which there is relatively strong local competition.

Hypothesis 4a: The stronger the position of Japanese industry in the world market, the more likely it is that a global plant configuration is chosen as opposed to an Asia-bound configuration. A West-bound plant configuration is most likely in case of competitive threats from US and EU firms and hence an intermediate position of Japanese industry in the world market.

\section{Core products and the strategic importance of the product line}

Different products manufactured by a firm may vary strongly in their strategic importance to the firm and their ability to affect overall performance and growth. Empirical studies informed by resource based theory and transaction cost theory have shown how firms optimize the exploitation of their proprietary assets in the extension of their product and geographical scope (e.g. Wolf, 1975; Delios and Beamish, 1999; Geringer et al. 2000). Chang (1995) has shown that firms are likely to invest abroad in their core business first and use this investment platform as an option to invest further in less central products after gaining knowledge on how to operate successfully in the overseas location. Hence, if we observe the presence of foreign manufacturing investment at any point in time, the probability of foreign investment is larger for core products than for non-core products.

Hypothesis 5. Firms are more likely to engage in manufacturing investment abroad for their core products.

In case a product constitutes a multinational firm's core business line, the firm is more likely to aspire to achieve a global presence and choose for a global plant configuration. Key resources and capabilities with potential scale economies will underlie the core businesses 
and are more likely to allow a configuration with multiple foreign plants. The strategic importance of the product forces the firm to seek profit opportunities in multiple markets and the option value of investments in core product manufacturing platforms abroad can be best utilized in a global configuration (Kogut, 1985).

Hypothesis 5a: A choice for a global plant configuration is more likely for core products.

\section{Internationalization experience}

Central to the resource based theory of multinational investment as well as the process view of internationalization (Johanson and Vahlne, 1977) is the role of managerial expertise and the acquisition and exploitation of knowledge how to operate in foreign countries. In this context, Casson (1994) examined internationalization as a corporate learning process. In his model, the cost of acquisition of information about a market is the main set-up cost of entry. Once these are incurred in an initial investment project in distribution activities, set-up cost for manufacturing investments decline. Investment in overseas distribution, after-sales service, and marketing increases sales growth potential, provides feedback on local market and investment conditions, and generally serves as a platform facilitating expansion into manufacturing. Japanese firms have been particularly active in establishing overseas distribution networks that have facilitated export growth (Yamawaki, 1991) and subsequent manufacturing investments. Empirical studies on foreign investment have found that previous experience in foreign markets positively affects the decision to invest in manufacturing (Hennart and Park, 1994; Belderbos, 1997a; Chang, 1995; Kogut and Chang, 1996).

Hypothesis 6: Foreign investment is more likely the more experience the firm has accumulated in operating abroad through earlier investments in foreign distribution activities.

\section{Technology intensity}

Besides a firm's competitiveness and market position in different product lines, the overall possession of intangible technological assets may have an additional effect on foreign investment. Competitiveness as measured by high domestic market shares may be based on the repeated introduction of innovative products, but also on brand image in the domestic market and investments in domestic distribution networks. Since technological advantages generally are more susceptible to transfer abroad than marketing advantages (e.g. Hennart 
and Park, 1994; Kimura, 1989), innovative firms are expected to have a higher propensity to invest abroad.

Hypothesis 7: Technology intensive firms are more likely to invest abroad.

Technological intensity may also affect the international plant configuration choice. It has been argued that Japanese firms locate production in advanced countries to benefit from technological spillovers (Kogut and Chang, 1991). The spillover argument is more important for firms with a strong absorptive capacity, which is reflected in their technological intensity (Veugelers, 1997; Cohen and Levinthal, 1990). Scope for such spillovers is by far the largest in developed markets such as the EU and the US. In addition, considering that technology intensive firms may use relatively more highly skilled labor, they may have a greater preference for manufacturing in developed markets. In this context, Fukao et al. (1994) found that R\&D intensive Japanese firms operate few manufacturing activities in Asia but larger scale manufacturing activities in the US and the EU.

Hypothesis 7a: Technology intensive firms are more likely to choose a West-bound configuration.

\subsection{Configuration-Specific Pull Factors}

So far we have introduced firm and industry characteristics that are decisive in the decision to invest abroad and that may have a differential impact across plant configurations. Another set of factors affecting the choice of plant configuration are location- or configuration- specific characteristics of the investment location. These are pull factors influencing the profitability of particular configurations and hence the likelihood that they are chosen.

\section{Trade protection: tariffs}

The tariff jumping argument for foreign investment holds that investment in a host country becomes relatively more attractive, the higher the import duties levied by the host country. Duties raise the cost of serving the host country market through exports from the home country or from export platform countries (Smith, 1987). Tariffs have been found to significantly affect inward investments (e.g. Belderbos, 1997a; Campa et al., 1998). 
Hypothesis 8: The higher the import tariff for a product in a region, the more likely it is that firms invest in manufacturing operations for the product in that region.

\section{Trade protection: antidumping and voluntary export restraints}

Besides conventional import duties, Japanese firms' exports to the EU and the US have been affected by voluntary export restraints and antidumping actions, and Japanese electronics producers have been major targets. Antidumping actions in particular remain a popular instrument of trade policy to protect domestic industries after GATT and WTO agreements have restricted or abolished he use of import duties and export volume restraints (Belderbos, 1997b). Both voluntary export restraints and antidumping actions have previously been found to impact on Japanese investments in the US and the EU (e.g. Belderbos, 1997a; Kogut and Chang, 1996; 1991; Drake and Caves, 1992).

Hypothesis 9: If in a region a Japanese firm's export product has been subject to antidumping actions or VERs, it is more likely that the firm invests in manufacturing operations for the product in that region.

\section{Market size}

Market size is an important locational pull factor attracting foreign investment (e.g. Head Ries and Swenson, 1995; Wheeler and Moody, 1992; Mayer and Muchielli, 1999). The larger the market, the more attractive local production becomes and the more likely it is that sales levels warrant the fixed costs of setting up local production facilities (Buckley and Casson, 1981; Smith, 1987; Motta, 1992). Likewise, the larger the market the greater the benefits of adaptation of products to local market conditions, which is facilitated by local production.

Hypothesis 10: The larger the market for the product in a region, the more likely it is that firms invest in manufacturing operations for the product in that region.

\section{Local experience}

Internationalization experience may be region-specific and therewith influence the choice of plant configuration. The more experience a firm has accumulated in a region, the lower the perceived risks and informational costs of entering the region through direct investment in 
manufacturing. Differences in regional experience can orient the firm towards a configuration building on the strongest regional experience and induce firms to expand investments in the region (e.g. Casson, 1995; Johanson and Vahlne, 1977).

Hypothesis 11: The more experience a firm has accumulated in a region through earlier investments in foreign distribution units, the more likely it is that the firm invest in manufacturing operations in that region.

\subsection{Control Variables}

In addition to the characteristics of firms, industries and locations for which we have derived hypotheses concerning their effects on foreign investment and the choice of plant configuration, we include a number of control variables for which we do not have a strong prior concerning their effects.

We include oligopolistic rivalry as a control variable in the plant configuration decision. Although Knickerbockers (1973) theory does not suggest any differentiation in the effect of domestic rivalry depending on the type of foreign market, it is conceivable that there are differences depending on the plant configuration, e.g. with rivalry being stronger when major markets are at stake. We also include firm size as a control variable. Firm size is often used as an indicator of economies of scale, which favors centralization of production in the home country. On the other hand, firm size may also reflect the ability of a firm to overcome financial barriers to invest in multiple foreign countries and to overcome institutional and other barriers to enter risky foreign markets (Caves, 1996: p.59; Belderbos and Sleuwaegen, 1996). Finally, we control for possible effects of membership of Japanese horizontal and vertical business groups (keiretsu) on investment decisions. Member firms of horizontal keiretsu may benefit from information exchange on foreign investment risks and local operations within the group (for instance information gathered by the general trading firm) and may be more able to finance risky foreign investment projects (Belderbos and Sleuwaegen, 1996; Chang, 1995). In vertical business groups, the presence of manufacturing networks abroad established by 'core' firms has been found to positively affect foreign investment decisions by related suppliers within the group. The latter can benefit from assistance, experience, and an exclusive overseas market provided by the 'core' firm 
(Belderbos and Sleuwaegen, 1996; Chang, 1995). This pattern of groups firms following the 'core' firm in it expansion abroad has been found to induce clusters of keiretsu manufacturing plants abroad (Head Ries and Swenson, 1994; Belderbos and Carree, 2000). However, we do not expect these supplier-assembler relationships to play a particularly important role in our analysis. Since we focus attention on consumer (final) goods industries, our sample mainly includes assembling firms and not the typical related suppliers within keiretsu group that produce components for supply to the 'core' firm and other group firms.

\section{EMPIRICAL METHODOLOGY AND DATA}

Following the arguments presented in the previous sections, the strategic choices concerning the decision to invest abroad and the particular plant configurations are considered as nested options in a structured decision model. The corresponding empirical model, which allows for a nested structure and differential impacts of firm and industry specific push factors as well as effects of configuration (location)-specific pull factors, is the nested multinomial logit model. We write the probability that firm $i$ in industry $j$ chooses a particular configuration $s$ as the product of the probability that the firm chooses to invest abroad $(f=1)$ and the probability that it chooses a particular international plant configuration, conditional on a positive foreign investment decision. Formally:

$$
\mathrm{P}_{\mathrm{ij}}^{\mathrm{s}}=\mathrm{P}_{\mathrm{ij}}^{f} \mathbf{P}_{\mathrm{ij} \mid \mathrm{f}=1}^{\mathrm{s}}
$$

The foreign investment choice $\mathrm{P}_{\mathrm{ij}}^{f}$ depends on firm and industry specific factors $X_{i j}$ and $Y_{j}$. If the firm decides to invest $(f=1)$ the firm has the option to choose one of the three international plant configurations. We write the profitability associated with the plant configurations $s$ as:

$$
\prod_{i j \mid f=1}^{s}=\alpha^{s}+\beta^{s} \ln X_{i j}+\gamma^{s} \ln Y_{j}+\delta \ln Z_{i j s}+\varepsilon_{i j s}
$$

Where $\alpha^{s}$ alpha is a configuration specific constant and $\varepsilon_{i j}^{\mathrm{s}}$ is an error term representing nonsystematic idiosyncratic factors. $X_{i j}$ are explanatory variables that may vary over firms and 
industries with coefficients $\beta^{s}, Y_{j}$ are variables that vary over industries with coefficients $\gamma^{s}$ and $Z_{i j s}$ are the configuration-specific (pull) variables that vary over configuration and industry or firm with coefficients $\delta$. If $\varepsilon_{i j}^{\mathrm{s}}$ has a Type I extreme value distribution, the conditional probability that configuration $s$ will generate the highest profits, and hence the conditional probability that the firm will choose configuration $s$, is described as a hybrid conditional logit model:

$$
\mathrm{P}_{\mathrm{ij \textrm {j } f}=1}^{\mathrm{s}}=\frac{\exp \left[\alpha^{s}+\beta^{s} X_{i j}+\gamma^{s} Y_{j}+\delta Z_{i j s}\right]}{\sum_{\mathrm{q}=1}^{3} \exp \left[\alpha^{s}+\beta^{s} X_{i j}+\gamma^{s} Y_{j}+\delta Z_{i j s}\right]}
$$

Equation (3) is a hybrid or 'McFadden' logit model combining a conditional logit specification (configuration-specific regressors $Z_{i j s}$ with generic coefficients $\delta$ ) with a multinomial logit specification (firm and industry-specific regressors $X_{i j}$ and $Y_{j}$ with configuration-specific coefficients $\beta^{s}$ and $\left.\gamma^{s}\right){ }^{4}$ To identify the model, the coefficients $\alpha, \beta$ and $\gamma$ have to be normalized to zero for one configuration. In the empirical analysis we will take the Asia-bound configuration as the reference choice. The generic coefficients $\delta$ do not vary by configuration and are estimated model-wide.

Turning back to the decision to invest abroad in the nested model, the probability of choosing foreign investment or not depends on the potential profitability contributions associated with the three options available for international plant configurations (see Figure 1). The sum of profit contributions of the conditional configuration choices is called the Inclusive Value (IV) and is defined as:

$$
\mathrm{IV}_{\mathrm{ij}}=\ln \left(\sum_{s=1}^{3} \alpha^{s}+\beta^{s} X_{i j}+\gamma^{s} Y_{j}+\delta Z_{i j s}\right)
$$

The Inclusive Value enters the probability of choosing to invest abroad in the first stage, which is expressed as:

\footnotetext{
${ }^{4}$ E.g. Greene, 1997; McFadden, 1984.
} 


$$
\mathrm{P}_{\mathrm{ij}}^{f}=\frac{1}{1+\exp \left[\alpha^{f}+\beta^{f} X_{i j}+\gamma^{f} Y_{j}+\sigma I V_{i j}\right]}
$$

Where $\sigma$ is the estimated impact of the configurations' profit contributions on the propensity to choose to invest abroad. The nested logit model described in equations (1)-(5) allows for a statistical test of the fit of the model compared with a standard multinomial logit model with domestic production and the three international plant configuration as same-level choices. In case $\sigma$ is equal to one, the unconditional probability to choose a specific configuration $\left(\mathrm{P}_{\mathrm{ij}}^{f} \mathrm{P}_{\mathrm{ijf} f=1}^{\mathrm{s}}\right)$ can be rewritten as a one-stage multinomial model with four choices, including a 'domestic' configuration (e.g. Greene 1997; Mayer and Muchielli 1999; Devereux and Griffith 1999). This would imply that we would have to reject the nested logit model in favor of the multinomial logit model. In addition, if $\sigma$ is zero, then the profit contributions of the plant configuration decisions do not affect the foreign investment decision and the nested model neither is appropriate (McFadden, 1984). Hence a test for the appropriateness and statistical validity of the nested decision structure is that $\sigma$ is both significantly different from one and zero. We followed the two-step procedure proposed by Greene (1997, p.923), by estimating first equation (3). From this estimation we calculated the inclusive values and included these in the estimation of equation (5).

\section{The Dataset}

We constructed a micro-level database of Japanese firms' plant establishments in the United States, the European Union, and Asia for 36 products in the electronics and precision machinery industries. ${ }^{5}$ The 36 electronics products (see Table 1) are all final goods in order to focus on products with comparable characteristics in terms of marketing channels and manufacturing organization. The products are defined at the four or five digit level, reflecting differences in product maturity between market segments (e.g. laptop vs. desktop computers, and LCD televisions vs. conventional televisions) and often detailed application of antidumping measures (e.g. dot matrix printers vs. laser printers). For each product, Japanese

\footnotetext{
5 Included are investments in the ASEAN nations (Indonesia, Malaysia, Thailand, Brunei, Singapore, Philippines), China, Hong Kong, Taiwan, and South Korea. Other countries in Asia (e.g. India, Vietnam) were also included but recorded few or no investments in the 36 industries.
} 
manufacturers were identified based on Japanese electronics industry data. ${ }^{6}$ After excluding foreign-owned firms this resulted in a comprehensive list of Japanese producers for each product. In total, the dataset includes 120 individual firms, of which 28 are privately held. The 120 firms on average manufactured between 4 and 5 products, resulting in a total number of firm-product combinations of 533. Fifteen observations had to be omitted because no data were available for the explanatory variables; this reduced the dataset to 518 observations. The dependent variable was created by determining whether the firms had set up manufacturing plants for each product (counting plants in operation in 1992) in the EU or US, and / or in Asia, using a variety of firm-level data sources. In 266 out of 519 cases foreign investment occurred. In the plant configuration choice analysis this gave us 266 decisions each on a set of 3 choice possibilities, hence 798 observations in McFadden's conditional logit model.

\section{Explanatory Variables}

We describe the definition of the explanatory variables employed to test our hypothesis. For convenience the hypothesized signs of the coefficients to be estimated are listed in Table 2 in addition to the means and standard deviations of the variables. In Table 2 and in the presentation of the results we normalized the coefficients for the Asia-bound configuration to zero. The signs in Table 2 therefore indicate the expected direction of the explanatory variables on the conditional probability that the West-bound and global configurations are chosen and not the Asia-bound configuration.

\section{INSERT TABLE 2}

The stage of the product cycle is measured as the number of years since the recorded start of production in Japan for each product. Since the marginal effect on the propensity to invest abroad of an additional year of product maturity is expected to be smaller at the highest levels of maturity, we include the natural logarithm of product maturity to test hypotheses 1 and 1a. ${ }^{7}$ Market share data (hypotheses 2 and 2a) were collected for the years 1990-1991 primarily

\footnotetext{
6 Mainly Denshi Keizai Kenkyuujo (1993) and Yano (1989-1995). An appendix with a detailed description of data sources and data construction can be obtained from the authors upon request.

${ }^{7}$ We also tested a linear as well as a quadratic specification and obtained similar but less significant results.
} 
from Yano (1990-1992). Since this source generally does not list the precise market shares for smaller players in the Japanese market, market shares could not be determined in percentage terms for a number of firms. We could classify firms into four groups: those with market shares smaller than 5 percent, with market shares between 5 and 10 percent, with market shares between 10 and 20 percent, and with market shares greater than 20 percent, respectively. The latter group we consider dominant firms; firms with market shares within the 10-20 percent range are competitive but non-dominant firms. Based on the market share data of individual firms we calculated the Herfindahl index in Japan for each product. We followed Shepherd (1997) in defining a loose oligopoly as an industry with a Herfindahl index greater than 1000 and smaller than $1800 .{ }^{8}$ Loose oligopoly is a dummy variable that takes the value 1 for such industries and tests Hypothesis 3. We collected data on Japanese industry's share of the world market in 1990-1992 (Hypotheses 4 and 4a) from various sources. ${ }^{9}$ Based on the information available, Japanese industry's world market share could be classified as low ( $<25$ percent), intermediate $(25-75$ percent $)$ or dominant ( $>75$ percent). The calculated world market shares show low competitiveness in most white goods sectors and computers but a dominant position in world markets for several consumer electronics products (e.g. CD players, VCRs, facsimile machines, cameras). In order to test Hypotheses 5 and 5a, we defined a core product as a product that is part of a firm's line of business that represents at least 10 percent of total turnover, based on information in the firms' financial reports. Internationalization experience is defined as the number of months since the establishment by the firm of its first sales subsidiary in the US, EU or Asia. Since the effect of an additional month or year of experience will be greater for firms that only recently invested in distribution compared to firms that have been active for, say, 20 years, we chose a logarithmic specification. ${ }^{10}$ Technology intensity (Hypothesis 7 and 7a) is measured as the number of patents in the five year period 1989-1993 granted to the firm or its subsidiaries by

${ }^{8}$ The Herfindahl-Hirschman index is defined as $\sum_{i=1}^{N}\left(\text { share }_{i}\right)^{2}$. We calculated the index by assuming that the market share that was not assigned to the larger players (on average around 5 percent) was evenly distributed over the smallest firms (for which no precise market share data was available).

${ }^{9}$ The main method was to add data on overseas production by Japanese firms to figures on domestic Japanese production and to divide this sum by the figure for world market volume.

${ }^{10}$ Since the number of months of overseas experience firms can be zero (for firms lacking a sales subsidiary abroad) we added 1 month to all observations before taking the natural logarithm. 
the US patent office, per 1 billion Yen of turnover. ${ }^{11}$

We calculated the tariffs that can be avoided by choosing a specific plant configuration as weighted averages of the tariff levels for each country or region (Hypothesis 8). As weights we used the relative size of the countries' markets for each product. Asian tariffs are weighted averages of pre-Uruguay Round tariffs in Taiwan, Malaysia, Thailand, South Korean, Hong Kong, and Singapore, the six largest electronics markets in Asia in the early 1990s. Westbound configuration tariffs are weighted averages of EU and US pre-Uruguay Round tariffs, and global configuration tariffs are weighted averages of tariffs in the other two configurations. US and EU tariffs vary between 2 and 10 percent while average tariffs in East Asia often reach higher than 30 percent for products such as color televisions, VCRs, and white goods. To control for this high variability in the explanatory variable and since we expect a larger marginal impact of tariff increases at moderate tariff levels, we include the natural logarithm of the average tariff for the configurations. The second configurationspecific trade policy variable concerns regional antidumping actions and voluntary export restraints targeting Japanese exporters (Hypothesis 9). In particular in the second half of the 1980s, a range of Japanese export products, among which mobile phones, PBX systems, CD players, computer diskettes, dot matrix printers, copiers, and typewriters, have been affected by the imposition of antidumping duties by the US or EU administrations. ${ }^{12}$ In addition, for a few products, Japanese exports to the US or the EU have been affected by VERs, quantitative restrictions, or punitary tariffs. ${ }^{13}$ Our antidumping \& VER measure of trade protection takes the value 1 if antidumping or other trade restrictions have targeted Japanese exports of the product to the US or the EU, and the value 2 if both the US and EU imposed such measures. This reflects that the incentives for trade barrier jumping investment are stronger if both these major markets are difficult to access through exports from Japan. Market size is a configuration-specific variable measuring the size of region's market as a percentage of the

\footnotetext{
11 See Belderbos (2001) for details on Japanese electronics firms' patenting intensity and a description of the data.

12 See Belderbos (1997b). Asian countries, such as Taiwan and South Korea, only recently have incorporated antidumping articles in their trade legislation.

13 VERs have been affecting Japanese CTV exports to both the US and the EU, the EU operated a VER for Japanese VCRs in the 1980s and national quota applied to import of stereo sets until 1992. The US imposed a punitive tariff on Japanese PCs imports during 1987-1991 in accordance with its Super 301 bilateral trade policy legislation.
} 
'Triad' markets (Western Europe, the US, and Japan/East Asia). It measures the relative importance of the foreign markets included in the plant configuration (Hypothesis 11). To capture regional experience effects, we include a variable measuring the number of months since a firm's first establishment of a distribution subsidiary in the region of the plant configuration (Hypothesis 11). In case of a global configuration, we took the average experience in Asia and the US/EU.

The control variable firm size is measured as the natural logarithm of the firm's turnover. Vertical keiretsu is a dummy variable taking the value one if the firm is listed as a member of one of the larger vertical manufacturing groups in Japan. Horizontal keiretsu is a similar dummy variable measuring horizontal keiretsu membership. ${ }^{14}$

\section{RESULTS}

The estimation results are presented in Table 3 for the decision to invest abroad (equation 5) and in Table 4 for the plant configuration decision conditional on a positive investment decision (equation 3). We first discuss the results concerning the decision to invest abroad.

\section{INSERT TABLE 3}

The estimated coefficients presented in Table 3 represent the marginal impact on the odds ratio of the probability of producing abroad relative to the probability of domestic production only. The model generally performs well, with all but one of the explanatory variables significant at the one or five percent levels. In 74 percent of the cases the foreign investment or domestic production choice is rightly predicted. The estimated coefficient for the Inclusive Value is 0.23 and lies within the hypothesized interval $\langle 0,1\rangle$. The coefficient is significantly different from zero at the 10 percent level if we adopt a conservative two-sided test, and

\footnotetext{
14 For vertical keiretsu we used the list provided in Dodwell Marketing Consultants' Corporate Groupings in Japan. For horizontal keiretsu we used the same source as well as a more elaborate Japanese language source, Keiretsu no Kenkyuu by Keizai Chousa Kyoukai (the membership definitions of Dodwell and Keizai Chousa Kyoukai differ for a number of firms). We obtained comparable results and report results obtained with the Keizai Chousa Kyoukai definition.
} 
significantly greater than zero at the 5 percent level under a one-sided test. This confirms the role of the second stage expected profitability associated with the different plant configurations in deciding to invest abroad or not. Furthermore, the coefficient of the Inclusive Value is significantly different from one (at the one percent level), confirming that the nested logit model cannot be reduced to a multinomial logit model. These results confirm the appropriateness of the structured decision model of the foreign investment and plant configuration choices.

The empirical results support the product cycle hypothesis (H1). Product maturity has a strong and positive effect on the decision to invest abroad. The results also show that higher domestic market shares significantly increase the probability to invest abroad, consistent with Hypothesis 2. The increasing value of the coefficients of market share up to the dominant market share level suggests that overall, non-dominant firms are not more likely to invest abroad compared with dominant firms. Firms in loosely knit oligopolistic industries show a significantly higher probability of investing abroad, confirming Hypothesis 3. Japanese industry's world market share has a positive and significant effect on investment abroad in support of Hypothesis 4, but the probability of investment is not monotonously increasing in world market share: there is no substantial difference between the coefficients of intermediate to high market shares and dominant shares. Hypothesis 5 is confirmed as core products of the firm are significantly more likely to be produced abroad than other products. The extent to which firms have accumulated experience in doing business abroad has a significant and positive impact on the foreign investment decision, in support of Hypothesis 6. The only hypothesis receiving no empirical support is Hypothesis 7: the coefficient of technology intensity has a counter-intuitive negative sign but is not significantly different from zero. Apparently the role of firm capabilities based on technology is well encompassed by the market share variable in the model (see Section 6). Among the control variables, no coefficient reaches statistical significance.

\section{INSERT TABLE 4}

Estimates of the first two sets of coefficients in Table 4 are the marginal impact on the odds ratio of a Japanese firm choosing a West-bound or global plant configuration as opposed to 
an Asia-bound configuration (the reference choice), conditional on a decision to invest abroad. The third set of coefficients represent the marginal impact on the odds ratio of choosing a West-bound configuration and not a global configuration. The latter coefficients are equal to the difference between the first and second sets of coefficients and are included in the table to enable direct inspection of the significant differences between global and Westbound configurations. The configuration-specific variables are variables of type $Z_{i j s}$ for which only one generic coefficient is estimated. For each configuration a constant term is estimated, which captures fixed effects associated with that configuration such as geographic location, the degree of cultural and economic integration with Japan, and macro economic factors such as labor and capital costs. ${ }^{15}$

The empirical model rightly predicts the chosen plant configuration in 78 percent of cases and the pseudo $\mathrm{R}^{2}$ reaches 0.317 , which is relatively high for conditional logit models. The empirical results support the product cycle hypothesis (H1a). Product maturity has a strongly significant negative effect on the probability that a West-bound configuration is chosen compared with an Asia-bound configuration. The probability of a global configuration is also negatively affected but in this case the coefficient is smaller and not significant. The difference between the coefficients for West-bound and global plant configurations is large and itself significant as is demonstrated by results in the third column where a global configuration is taken as reference state. The results are consistent with a pattern in which a West-bound configuration is chosen for novel products, a global configuration for products in intermediate stages of the product cycle, and an Asia-bound configuration for the most mature products. The results by and large support Hypothesis 2a. Market shares in the 10-20 percent and greater than 20 percent ranges have a significantly positive impact on the probability of choosing a global configuration as opposed to an Asia-bound configuration, whereas the coefficient of a market share in the 5-10 percent range just fails to reach conventional significance levels. As hypothesized, non-dominant firms (with market shares in the 10-20 percent range) have a higher probability of choosing a West-bound configuration as opposed to an Asia-bound configuration, but the results do not suggest that non-dominant firms prefer West-bound over global configurations (the coefficient in the third column is

\footnotetext{
15 Given the dummy structure of the model, the estimated constant term represents the fixed effect for firms manufacturing a non-core product with a market share small than 5 percent in industries with low Japanese world market shares not characterized by a loosely oligopolistic structure.
} 
negative but not significantly different from zero). The results for dominant firms (with market shares greater than 20 percent) are unambiguous: these prefer global configurations to West-bound as well as Asia-bound configurations as predicted. Hypothesis 4a finds partial support in the results. The higher Japanese industry's competitiveness expressed by its world market share, the more likely it is that firms in the industry choose a global plant configuration. In case of a dominant position of Japanese industry, firms are significantly more likely to choose a global configuration and not Asia- or West-bound configurations, as hypothesized. On the other hand, firms in non-dominant but competitive Japanese industries (market shares in the 25-75 percent range), are not significantly more likely to choose a West-bound configuration. Hypothesis 5a finds strong support in the results: if a product belongs to a core business of the firm, the firm is significantly more likely to choose a global plant configuration as opposed to both the Asia- and West-bound configurations. Technology intensity has the hypothesized positive effect on the probability that a West-bound configuration is chosen. The estimated effect is significant in comparison with the choice for a global configuration, partially confirming Hypothesis 7a.

With the exception of the regional experience variable, all configuration-specific regional pull variables have the expected sign. The average level of import tariffs in the region (Hypothesis 8) has a positive effect but fails to reach conventional significance levels. The existence of VERs and the imposition of antidumping measures has a strongly significant effect on the plant configuration choice, confirming Hypothesis 9. The positive and significant effect of regional market size confirms Hypothesis 10. The coefficient of regional experience is insignificant with a counter-intuitive negative sign, rejecting Hypothesis 11.

Among the control variables, firm size has a positive and significant effect on the probability of choosing a West-bound or global plant configuration, which is in line with earlier empirical studies (e.g. Belderbos and Sleuwaegen, 1996; Horiuchi, 1989). The significant effect of the loose oligopoly dummy variable on the probability of choosing a global configuration compared to both Asia-bound and West-bound configurations suggests that the follow the leader behavior in foreign investment in loosely oligopolistic industries is played out on a global scale rather than at a regional level. Membership of horizontal or vertical keiretsu has no significant effect either on the investment decision or the plant configuration decision. The finding on horizontal keiretsu contrasts with Chang (1995) but is more in line with Belderbos and Sleuwaegen (1996) and Hunley (1998) who found mixed effects of 
horizontal keiretsu membership. Hunley (1998) suggests that the cartel-like properties of horizontal keiretsu shield firms from competition and so provides fewer incentives for innovation and competitive achievement on world markets. The absence of an effect of vertical keiretsu membership is consistent with the view that the effects of vertical keiretsu on foreign investment decisions works primarily through supplier-assembler linkages (Belderbos and Carree, 2000; Head Ries and Swenson, 1995). Since our sample only includes final (consumer) goods industries, these linkages play a lesser role in our empirical model.

\section{DISCUSSION AND CONCLUSION}

Overall, the empirical results lend strong support to the notion of a structured push-pull decision model of internationalization of production in which different international plant configurations are treated as nested strategic options of the decision to invest abroad. Firm resources and competitiveness, domestic and overseas competition, and changing technological conditions related to the product cycle push firms to invest abroad. These factors have a differential impact on the subsequent choice of international plant configuration, while this choice is also affected in a major way by locational pull factors such as restrictive trade policies and foreign market size.

A central question analyzed in this study was the extent to which the product cycle contributes to the explanation of the internationalization of firms. We tested a key hypothesis of product cycle theory: that the standardization and maturity of the technology associated with the stage of the product cycle impacts on the foreign investment decision as well as the choice of plant configuration. This impact should remain after controlling for firm, industry and locational characteristics hypothesized to affect the foreign investment and plant configuration decisions based on other theories of multinational investment, such as internalization theory, resource based theory, the process theory of internationalization, and the theory of oligopolistic rivalry. Our findings suggest that the product cycle model has not lost its significance in explaining international production in the 1980s and early 1990s. Both the decision to invest abroad and the choice of particular plant configurations are significantly affected by product maturity. The results are consistent with a pattern of investment in the EU and the US in the early stages, extending to a global plant configuration in intermediate stages, and a concentration of manufacturing activity in Asia in the final 
stages of the product cycle. At the same time, the results do not reject the notion of 'sprinkler' type simultaneous marketing and manufacturing of products as long as it concerns expansion in developed foreign markets. The strongly negative effect of product maturity on the choice of a West-bound plant configuration with foreign manufacturing activity limited to the EU and US suggests that product maturity is not necessarily a major consideration for firms choosing this focused configuration of plants. Other explanations, such as the need to jump trade barriers and the search for overseas (R\&D) resources in the face of strong overseas competition play more important roles.

The empirical results on international plant configuration choice showed further significant differences between the two configurations that include manufacturing plants in the Western markets of the EU and the US: a global vs. a West-bound plant configuration. A global configuration is more likely to be chosen if the firm has a dominant position in the Japanese market, in case Japanese industry is dominating the world market, and if investment concerns one of the firm's core product, but is less likely to be chosen by the most technology intensive firms. This suggests that previous research limiting analysis to the determinants of (Japanese) investment in a particular region or country may obscure a number of important aspects of internationalization strategies. The fact that a firm invests in the US or the EU in itself does not reveal information on the firms' internationalization strategy and plant configuration choice, which in turn is associated with a substantial variability in firm-level competitiveness and technological intensity as well as different conditions in the Japanese and global industry.

The clear rejection of Hypotheses 7 and 11 merits further discussion. The counter-intuitive negative but insignificance coefficient of technology intensity rejecting Hypothesis 7 appears at odds with a large body of existing literature on foreign investment, which has found significantly positive effects of the possession of intangible assets (Caves 1996). One explanation is that the inclusion in the empirical model of market share data at the product level, in addition to a measure of Japanese industry world competitiveness, sufficiently expresses the impact of the relevant intangible assets in terms of product-level competitiveness. Market share has also in other studies appeared to be a superior predictor of foreign investment (Caves 1996, p.59). In addition, with a given level of competitiveness as measured by market share, higher overall $R \& D$ intensity of the firm may indicate a stronger emphasis on improving margins through increased quality and performance of existing 
product lines. This is likely to require continuous interaction between $R \& D$ centers and manufacturing operations favoring the location of production in Japan (cf. Dubois et al., 1993; Belderbos, 2001). The negative, but again insignificant effect of regional experience on the choice of plant configuration (rejecting Hypothesis 11) contrasted with a strongly positive and significant effect of internationalization experience on the decision to invest abroad. While the first steps in the internationalization process in terms of gathering information on foreign markets and operating marketing and distribution affiliates are important for the foreign investment decision, the choice of plant configuration is less experience dependent but determined by the attractiveness of the different regions for investment (market size and market access). The latter result is inconsistent with the stage theory of internationalization, but we note two possible caveats. First, experience effects are most pronounced at the country level and our more aggregated regional level analysis may not adequately measure these effects. Second, a proper test of stage theories has to adopt a longitudinal empirical approach, which goes beyond the cross section nature of our data (see below).

Our use of micro-data at the level of the product and the firm may contribute to a better understanding of the different motives for investing abroad in relation to the plant configuration chosen by the firm. Four motives of foreign investment have been distinguished: defensive trade barrier circumvention (tariff jumping investment), offensive market access and technology acquisition, market diversification, and cost reduction (e.g. Dunning 1993). The latter two motives are consistent with the product cycle model, where diversification motives make firms opt for a global plant configuration and where cost reduction pushes firms to concentrate production in Asia in the later stages of the product cycle. The former two motives, on the other hand, deviate from it. The strong effect of trade policy measures on the choice of plant configuration shows that firms can be pulled towards foreign production in a West-bound configuration quite apart from product maturity considerations, as suggested by Ohmae (1985). This corroborates previous empirical findings of substantial effects of antidumping measures on (Japanese) investments in the US and the EU (Belderbos, 1997a; Barrell and Pain, 1999). Offensive market access and technology acquisition likewise has an impact mainly on investments in the developed markets of the EU and the US only. A West-bound plant configuration is less likely to be chosen by dominant firms and in industries with relatively little world-wide competition (a dominant position of Japanese industry), but is more likely to be chosen by technologically firms. These investments are likely to be made in order to gain access to foreign technology and in order to 
learn from overseas market experience and may also include acquisitions of foreign firms. This finding is consistent with the important role of technology sourcing and acquisitions in the expansion of Japanese firms' R\&D operations in the US and the EU (Belderbos, 2001).

\section{Limitations and further research}

In concluding we point out some important limitations of our study and suggest possible avenues for further research. The main limitation of our research we consider the cross section nature of the micro level data. Although the inclusion of a variety of products at different phases of the product cycle allowed us to assess the impact of product maturity on international production, the cross section nature of the data is not well suited to uncover paths of dynamic internationalization processes. While our results on West-bound plant configurations are consistent with the notions of growing convergence of developed markets and industries across countries (Dicken, 1998) and short product cycles, we are unable to test whether product cycles have shortened over time. There are two contrasting hypotheses concerning dynamic internationalization processes. McDougall et al. (1994) and Bell (1995) argue that many international new ventures at the product level are radically and quickly implemented in all developed markets. For such ventures international competencies are of great importance and there is only limited dependence on domestic competencies and growth. This globalization model in which firms exploit the domestic and major foreign markets in a simultaneous fashion, contrasts with an incremental approach to internationalization described in the process view of international investment (Johanson and Wiedersheim-Paul, 1975; Johanson and Vahlne, 1977). Testing these alternative hypotheses would necessitate the use of longitudinal data, preferably by extending or repeating the dataset up to the late 1990s. Given the formidable task of gathering the micro-level data, we consider this a major challenge for future research.

A second limitation is that we did not examine the relationship between different plant configurations and performance. Findings in Beamish and Delios (1999) suggest that geographic scope of operations has a separate positive feedback on performance of Japanese

firms, which they attribute to increased scale economies and cost reduction as well as potential benefits of technology spillovers and global learning. Geringer et al. (2000) found more mixed effects of international diversification on Japanese firm performance. Our model 
suggests that the appropriateness and profitability of different levels of geographic scope in international production depend on the push and pull factors affecting the firm in the specific product market. Depending on firm resources, domestic and foreign competition, and the stage of the product cycle, a more limited scope of overseas production may results in a better performance than a wider scope. The mixed findings on the relationship between performance and geographic scope in the existing literature may stem from aggregation bias when summing over the different product markets in which the firm is active. Our more detailed predictions concerning the international operations of firms at the product level suggest that future research on (geographic) diversification and performance should attempt to analyze this relationship at the business unit level rather than at the firm level.

More detailed insight into the rationale of different international plant configurations could also be obtained with more precise information on the geographic mandate of the manufacturing operations abroad. In particular in Asia, a distinction can be made between plants exporting to EU and US markets, and plants serving the local or Asian markets. Such a distinction would allow us to trace further to what extent firms have rationalized their global operations along their internationalization path (Douglas and Craig, 1992; Sleuwaegen, 1992) or have circumvented European and US trade barriers by setting up operations in other Asian countries. Further research could aim to set up global profiles of firms and determine the scope of their operations, which would enable further decomposition of international manufacturing strategies. A final and obvious limitation is the restriction of our data to the (broadly defined) electronics sector and to Japanese firms, for which the internationalization process is of a much more recent origin than for Western firms. Comparative research using data on other industries and US or European firms could bring out the major similarities and dissimilarities.

\section{REFERENCES}

Anderson O. (1994). On the Internationalization Process of Firms: a Critical Analysis. Journal of International Business Studies, 25, pp. 209-231

Barrel, R. and N. Pain (1999). 'Trade restraints and Japanese direct investment flows', European Economic Review, 43 (1), pp. 29-45. 
Bartlett, C.A. and S. Ghoshal (Summer 1987). 'Managing across borders: New strategic requirements', Sloan Management Review, pp. 7-17.

Bartlett, C.A. and S. Ghoshal (2000). Text, Cases and Readings in Cross-Border Management. Irwin McGraw-Hill, pp. 29-41.

Belderbos, R.A. (2001). Overseas Innovations by Japanese Firms: An Analysis of Patent and Subsidiary Data, Research Policy, Vol. 30 (2), 313-332, 2001.

Belderbos, R.A. (1997a). 'Antidumping and Tariff Jumping: Japanese Firms' DFI in the European Union and the United States', Weltwirtschaftliches Archiv, 133 (3), pp. 419-457.

Belderbos, R.A. (1997b). Japanese Electronics Multinationals and Strategic Trade Policies. Oxford University Press, Oxford.

Belderbos, R.A and M. Carree (2000.) 'The Location of Japanese Investments in China: Agglomeration Effects, Keiretsu, and Firm Heterogeneity', NIBOR (Netherlands Institute of Business Organization and Strategy Research) Research Memorandum RM/00/02, Faculty of Economics and Business Administration, Maastricht University.

Belderbos, R. A. and L. Sleuwaegen (1996). 'Japanese Firms and the Decision to Invest Abroad: Industrial Groups and Regional Core Networks', Review of Economics and Statistics, 78, pp. 214-220.

Bell, J. (1995). 'The internationalization of small computer software firms, A further challenge to 'stage' theories', European Journal of Marketing, 29 (8), pp. 60-75.

Birkinshaw J., A. Morrison and J. Hulland (1995). 'Structural and Competitive Determinants of A Global Integration Strategy', Strategic Management Journal, 16, pp. 637-655.

Buckley, P. J. and M. Casson (1976). The Future of Multinational Enterprise. New York: Holmes \& Meier.

Buckley, P. J. and M. Casson (1981). 'The optimal timing of foreign direct investment, Economic Journal, 91, pp. 75-87.

Campa, J., S. Donnenfeld and S. Weber (1998). 'Market Structure and Foreign Direct Investment', Review of International Economics, 6, pp. 361-380.

Cantwell, J. (1995). 'The globalisation of technology: what remains of the product cycle model', Cambridge Journal of Economics, 19, pp. 155-174.

Caves, R.E. (1971). International Corporations: the Industrial Economics of Foreign Investment, Economica 38, pp. 1-27.

Caves, R. E. (1996). Multinational Enterprise and Economic Analysis, second edition. MIT Press, Cambridge, MA. 
Caves, R. E., M. E. Porter and A. M. Spence with J. T. Scott (1980). Competition in the Open Economy: a Model Applied to Canada. Harvard University Press, Cambridge, MA.

Chang , S.J. (1995). 'International Expansion Strategy of Japanese Firms: Capability Building Through Sequential Entry', Academy of Management Journal, 38, pp. 383-407.

Cohen, W. and D. Levinthal (1990). 'Absorptive Capacity: A New Perspective on Learning and Innovation', Administrative Science Quarterly, 35, pp. 128-152.

Collis, D.J. (1991). A resource-based Analysis of Global Competition: the Case of the Bearing Industry, Strategic Management Journal 12 (Special issue, summer), pp. 49-68.

Davidson W.H. (1980). The Location of Foreign Direct Investment Activity: Country Characteristics and Experience Effects, Journal of International Business Studies 11,pp. 922.

Delios, A. and P. W. Beamish (1999). 'Geographic Scope, Product Diversification, and the Corporate Performance of Japanese Firms', Strategic Management Journal, 20, pp. 711727.

Denshi Keizai Kenkyuujo (1993). Denshi Kiki Buhin Meikah Risuto (Directory of Electronics Equipment and Components Manufacturers), Tokyo: Denshi Keizai Kenkyuujo.

Devereux, M. P. and R. Griffith (1999), 'Taxes and the Location of Production: Evidence from a Panel of US Multinationals', Journal of Public Economics, 68, pp. 335-367.

Dicken, P. (1998). Global shift: transforming the world economy, third edition. Paul Chapman Publishing ltd., London.

Douglas, S. and S. C. Craig (1992), 'Advances in International Marketing', International Journal of Research in Marketing, 9 (4), pp. 291-319.

Drake, T. A. and R. E. Caves (1992). 'Changing Determinants of Japan's Foreign Investment in the United States', Journal of the Japanese and International Economies, 6, pp. 228-246.

Dubois, F. L., B Toyne, and M. D. Oliff (1993) International manufacturing strategies of U.S. multinationals, Journal Of International Business Studies, 24 (2), pp. 307-333.

Dunning, J. H. (1993). Multinational Enterprises and the Global Economy. Addison Wesley, Harlow.

Fina E. and A.M. Rugman (1996). A Test of Internalization Theory and Internationalization Theory: The Upjohn Company, Management International Review 36, pp.199-213.

Fukao, K., T. Izawa, M. Kuninori and T. Nakakita (1994). 'R\&D Investment and Overseas Production: An Empirical Analysis of Japan's Electric Machinery Industry Based on Corporate Data', BOJ Monetary and Economic Studies, 12, pp. 1-60. 
Geringer, M. J., S. Tallman and D. M. Olsen (2000). 'Product and International Diversification among Japanese Multinational Firms', Strategic Management Journal, 21, pp. 51-80.

Head, K., J. Ries and D. Swenson (1995). 'Agglomeration Benefits and Location Choice: Evidence from Japanese Manufacturing Investments in the United States', Journal of International Economics, 38, pp. 223-247.

Hennart, M.T. (1982). A Theory of the Multinational Enterprise, Ann Arbor, MI: The University of Michigan Press.

Hennart, J.-F. and Y.-R. Park (1994). 'Location, Governance, and Strategic Determinants of Japanese Manufacturing Investments in the United States', Strategic Management Journal, 15, pp. 419-436.

Horiuchi, T. (1989). 'The flexibility of Japanese small and medium-sized firms and their foreign direct investment'. In K. Yamamuro (ed.), Japanese investment in the United States: should we be concerned. Society for Japanese Studies, Seattle, WA.

Hundley, G. and C. J. Jacobson (1998). 'The Effects of Keiretsu on the Export Performance of Japanese Companies: Help or Hindrance?', Strategic Management Journal, 19, pp. 927937.

Ito, K. and V. Pucik (1993). 'R\&D Spending, Domestic Competition, and Export Performance of Japanese Manufacturing Firms', Strategic Management Journal, 14, pp. 61-75.

Johanson, J. and F. Wiederheim-Paul (1975). 'The internationalization of the firm: Four Swedish cases', Journal of Management Studies, 12 (3), pp. 305-322.

Johanson, J. and J. E. Vahlne (1977). 'The Internationalization of the Firm. A model of Knowledge Development and Increasing Foreign Market Commitments', Journal of International Business Studies, 8, pp. 23-32.

Johanson, J. and J. E. Vahlne (1990). The Mechanism of Internationalization. International Marketing Review 7(4),pp. 11-24.

Kalish, S., V. Mahajan and E. Muller (1995). 'Waterfall and sprinkler new-product strategies in competitive global markets', International Journal of Research in Marketing, 12, pp. 105119.

Kimura, Y. (1989) 'Firm-specific Advantages and Foreign Direct investment Behavior of Firms: The case of Japanese Semiconductor Firms', Journal of International Business Studies, 20, pp.296-314.

Knickerbocker, F.T. (1973). Oligopolistic Reaction and the Multinational Enterprise. Cambridge, Harvard University Press. 
Kogut, B. (1985). 'Designing global strategies: profiting from operation flexibility', Sloan Management Review, 27 (1), pp. 27-38.

Kogut, B. and S. J. Chang (1991). 'Technological Capabilities and Japanese Foreign Direct Investment in the United States', Review of Economics and Statistics, 73, pp. 400-413.

Kogut, B. and S. J. Chang (1996). 'Platform Investments and Volatile Exchange Rates: Japanese Direct Investment in US Electronic Industries', Review of Economics and Statistics, 78, pp. 221-231.

Kogut, B. and N. Kulatilaka (1994). 'Operational Flexibility, Global Manufacturing, and the Option Value of a Multinational Network', Management Science, 40 (1), pp. 123-139.

Kogut, B. and U. Zander (1993). Knowledge of the Firm and the Evolutionary Theory of the Multinational Corporation, Journal of International Business Studies, 24 (4), pp. 625-645.

Kinoshita, Yuko, and Ashoka Mody (1997). The Usefulness of Private and Public Information for Foreign Direct Investment Decisions, Policy Research Working Paper 1733, The World Bank, Washington DC.

Krugman P. (1991). Geography and Trade, MIT Press, Cambridge MA.

Martin, X. and R. Salomon (2000). Tacitness, Learning, and International Expansion in a Knowledge-Intensive Industry, paper presented at the Academy of International Business Meetings, Phoenix AZ, 17-21 November 2000.

Mascarenhas, B. (1986). 'International Strategies of Non-Dominant Firms', Journal of International Business Studies, 17, pp. 1-25.

Mayer, T. and J.-L. Muchielli (1999). Hierarchical Location Choice and Multinational Firm Strategy, paper presented at the Western Economic Association conference at Lake Tahoe, June 28- July 2, 1998.

McCormack, A. D., L. J. Newman III and D. B. Rosenfield (1997). 'The New Dynamics of Global Manufacturing Site Location'. In L. H. Wortzel and H. Vernon-Wortzel (eds.), Strategic Management in a Global Economy. John Wiley, Chichester.

McDougall, P. P., S. Shane and B. McOviatt (1994). 'Explaining the formation of international new ventures: the limits of theories from international business research', Journal of Business Venturing, 9, pp. 469-487.

McFadden, G. S. (1984). 'Econometric Analysis of Qualitative Response Models'. In Z. Griliches and M.D. Intriligator, Handbook of Econometrics, Vol. 2. Elsevier, Amsterdam.

Mitchell, W., J. M. Shaver and B. Yeung (1992). 'Getting there in a global industry: impacts on performance of changing international presence', Strategic Management Journal, 13 (6), pp. 419-432. 
Morrisson, A. J. and K. Roth (1992). 'A Taxonomy of Business-Level Strategies in Global Industries', Strategic Management Journal, 13 (6), pp. 399-417.

Motta, M. (1992). 'Multinational Firms and the Tariff Jumping Argument: A Game Theoretical Analysis with some Unconventional Conclusions', European Economic Review, 36, pp. 1557-1571.

Ohmae, K. (1985). Triad Power: the Coming Shape of Global Competition, The Free Press, New York.

Ozawa, T. (1991). 'Japan in a New Phase of Multinationalism and Industrial Upgrading: Functional Integration of Trade, Growth, and FDI', Journal of World Trade, 25, pp. 43-60.

Porter, M. E. (1986). 'Competition in Global Industries: A Conceptual Framework'. In M. E. Porter (ed.), Competition in Global Industries. Harvard Business School Press, Boston, MA.

Pugel, T. A., E. S. Kragas and Y. Kimura (1996). 'Further Evidence on Japanese Direct Investment in US Manufacturing', Review of Economics and Statistics, 78, pp. 208-213.

Root F.R. (1987). Entry Strategy for International Markets. Lexington Books, pp. 1-23.

Shepherd, W. G. (1997). The Economics of Industrial Organization, $4^{\text {th }}$ edition. Prentice Hall, Upper Saddle River, NJ.

Sleuwaegen, L. (1992). 'Advances in International Marketing: Comments', International Journal of Research in Marketing, 4 (2), pp. 319-324.

Smith, A. (1987). 'Strategic Investment, Multinational Corporations and Trade Policy', European Economic Review, 31, pp. 89-96.

Teece, D.J. (1977). 'Technology Transfer by Multinational Corporations: the Resource Cost of Transferring Technological Know-How', Economic Journal, 87, 242-261.

Thomsen, S. (1993). 'Japanese Direct Investment in the European Community: The Product Cycle Revisited', World Economy, 16, pp. 301-315.

Vernon, R. (1966). 'International Investment and international Trade in the Product Cycle'. Quarterly Journal of Economics, 80, pp. 190-207.

Vernon, R. (1974). The Location of Industry. In: Dunning J.H., Economic Analysis and the Multinational Enterprise, pp. 89-114. London: Allen \& Unwin

Vernon, R. (1979). 'The Product Cycle Hypothesis in a New International Environment', Oxford Bulletin of Economics and Statistics, 41, pp. 255-267.

Veugelers, R. (1997), 'International R\&D expenditures and external technology sourcing', Research Policy, 26, pp. 303-315. 
Wolf, B.N. (1977). 'Industrial Diversification and Internationalization: Some Empirical Evidence', Journal of Industrial Economics, 26, pp. 177-91.

Yamawaki, H. (1991). 'Exports and Foreign Distributional Activities: Evidence on Japanese Firms in the United States', Review of Economics and Statistics, 73, pp. 294-30.

Yano Keizai Kenkyuujo, 1989-1995. Nihon Market Share Jiten (Japan Market Share Handbook). Mitsutomosha, Tokyo.

Yip, G. S. (1995). Total global strategy: managing for worldwide competitive advantage. Prentice-Hall, Englewood Cliffs, NJ.

Yu, C.-M. J., and K. Ito (1988). 'Oligopolistic Reaction and Foreign Direct Investment: the Case of the US Tire and Textiles Industries', Journal of International Business Studies, 19, 449460. 
FIGURE 1: Internationalization and Plant Configuration in a Structural Model of Nested Decisions

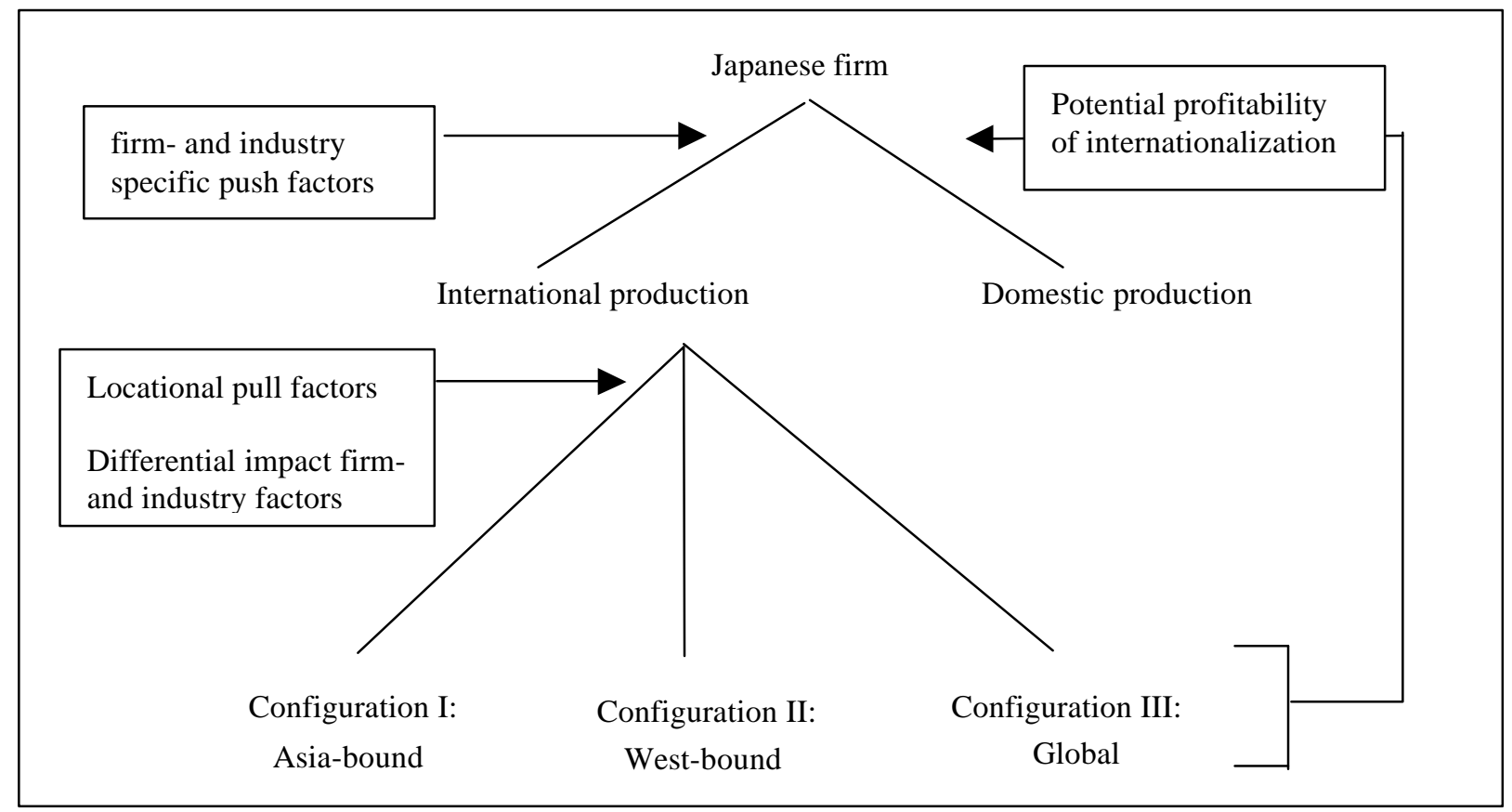


Table 1: Foreign Investment and Plant configuration Choices by Product

\begin{tabular}{|c|c|c|c|c|c|}
\hline & $\begin{array}{r}\text { Domestic } \\
\text { Production }\end{array}$ & $\begin{array}{l}\text { Asia- } \\
\text { bound }\end{array}$ & $\begin{array}{l}\text { West- } \\
\text { bound }\end{array}$ & Global & Total \\
\hline Airconditioners & 2 & 5 & 0 & 5 & 12 \\
\hline Audiotapes & 5 & 0 & 2 & 2 & 9 \\
\hline Calculators & 3 & 6 & 0 & 0 & 9 \\
\hline Camcorders & 9 & 0 & 0 & 1 & 10 \\
\hline Cameras & 2 & 8 & 0 & 0 & 10 \\
\hline Car audio & 7 & 4 & 2 & 7 & 20 \\
\hline CDPs & 10 & 5 & 4 & 7 & 26 \\
\hline Cellular Mobile Phones & 13 & 0 & 3 & 5 & 21 \\
\hline Copiers & 9 & 2 & 5 & 2 & 18 \\
\hline CRT TVs & 2 & 5 & 0 & 9 & 16 \\
\hline Desktop PCs & 15 & 3 & 1 & 1 & 20 \\
\hline Dot matrix printers & 6 & 2 & 7 & 6 & 21 \\
\hline Facsimiles & 15 & 1 & 4 & 7 & 27 \\
\hline FDD & 7 & 7 & 0 & 4 & 18 \\
\hline HDD & 15 & 0 & 3 & 2 & 20 \\
\hline headphone stereo & 3 & 6 & 0 & 0 & 9 \\
\hline Inkjet printers & 5 & 0 & 0 & 1 & 6 \\
\hline Laser printers & 21 & 0 & 4 & 0 & 25 \\
\hline Laser Disk Players & 14 & 0 & 0 & 0 & 14 \\
\hline LCD TVs & 11 & 2 & 0 & 0 & 13 \\
\hline Microdisks & 9 & 0 & 8 & 0 & 17 \\
\hline MWOs & 4 & 0 & 4 & 2 & 10 \\
\hline Pagers & 11 & 0 & 0 & 3 & 14 \\
\hline PBX & 11 & 1 & 6 & 2 & 20 \\
\hline Portable PCs & 10 & 0 & 4 & 3 & 17 \\
\hline Projection TVs & 1 & 0 & 7 & 0 & 8 \\
\hline radiocassetteplayers & 6 & 10 & 0 & 1 & 17 \\
\hline Refrigerators & 3 & 6 & 0 & 1 & 10 \\
\hline Stereosets & 2 & 11 & 3 & 7 & 23 \\
\hline Typewriters & 6 & 0 & 5 & 1 & 12 \\
\hline Vacuum cleaners & 5 & 1 & 1 & 1 & 8 \\
\hline Videotapes & 4 & 0 & 3 & 2 & 9 \\
\hline VTRs & 6 & 0 & 2 & 12 & 20 \\
\hline Washing machines & 3 & 5 & 0 & 0 & 8 \\
\hline Watches & 1 & 3 & 0 & 2 & 6 \\
\hline Workstations & 4 & 0 & 6 & 0 & 10 \\
\hline Total & 260 & 93 & 84 & 96 & 533 \\
\hline
\end{tabular}


Table 2: Explanatory Variables: Hypotheses, Means and Standard Deviations

\section{Variable}

Firm and Industry characteristics

Product cycle (ln years)

firm market share 5-10\% (dummy)

firm market share $10-20 \%$ (dmmy)

firm market share $20-60 \%$ (dummy)

Loose oligopoly (dummy)

Japan world market share $>25 \%,<75 \%$ (dummy)

Japan world market share $>75 \%$ (dummy)

Core product (dummy)

Internationalization Experience (ln months)

Technology intensity (US patents per 1 bln Yen sales)

Inclusive Value (IV)

\section{Configuration specific variables}

Tariffs (ln \%)

Antidumping \& VERs (dummy)

Market size (\% of 'Triad' market)

Regional Experience (ln months)

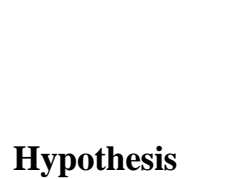

\section{Investmen Decision}
H1, H1a
$\mathrm{H} 2, \mathrm{H} 2 \mathrm{a}$
$\mathrm{H} 2, \mathrm{H} 2 \mathrm{a}$
$\mathrm{H} 2, \mathrm{H} 2 \mathrm{a}$

H3

$\mathrm{H} 4, \mathrm{H} 4 \mathrm{a}$

$\mathrm{H} 4, \mathrm{H} 4 \mathrm{a}$

$\mathrm{H} 5, \mathrm{H} 5 \mathrm{a}$

H6

$\mathrm{H} 7, \mathrm{H} 7 \mathrm{a}$

H9

H10

H11

+
+
+
+
+
+
+
+
+
+
$0<\mathrm{IV}<1$

Expected Sign:

\section{Control Variables}

Vertical keiretsu (dummy)

Horizontal keiretsu (dummy)

Firm size (ln sales)

\section{Configuration \\ Decision \\ US EU}

Global

Mean Std. Dev.

$--$

$+$

$+$

$-$

$+$

-

$\begin{array}{lll}- & 2.567 & 0.636 \\ + & 0.108 & 0.311 \\ + & 0.162 & 0.369 \\ + & 0.087 & 0.282 \\ & 0.545 & 0.498 \\ + & 0.615 & 0.487 \\ + & 0.254 & 0.454 \\ + & 0.775 & 0.418 \\ & 5.401 & 1.462 \\ 0 & 1.027 & 1.275 \\ & 3.841 & 1.205\end{array}$

$+$

3.84

2.430

0.476

0.555

5.425

0.651

0.675

0.311

1.111

$\begin{array}{rr}0.592 & 0.492 \\ 0.326 & 0.469 \\ 12.931 & 1.726\end{array}$

Notes: Hypothesized signs for the configuration decision are relative to the choice for an Asia-bound configuration (the reference state). Means and standard deviations for 518 choosers (observations) for firm and industry characteristics and control variables, and for 266 choosers $\mathrm{x} 3$ choices (798 observations) for configuration specific variables. 
Table 3. Logit Model of the Decision to Establish a Plant Abroad

\begin{tabular}{|c|c|c|}
\hline & coefficient & $\begin{array}{r}\text { t-ratio } \\
\text { (asymptotic) }\end{array}$ \\
\hline \multicolumn{3}{|l|}{ Firm and Industry characteristics } \\
\hline Product cycle & 0.86 & $4.30 * * *$ \\
\hline firm market share $5-10 \%$ & 1.20 & $3.31 * * *$ \\
\hline firm market share $10-20 \%$ & 1.84 & $4.81 * * *$ \\
\hline firm market share $>20 \%$ & 2.59 & $4.95 * * *$ \\
\hline Loose oligopoly & 0.56 & $2.29 * *$ \\
\hline Japan world market share $>25 \%,<75 \%$ & 1.02 & $2.70 * * *$ \\
\hline Japan world market share $>75 \%$ & 0.94 & $2.33 * *$ \\
\hline Core product & 0.78 & $2.97 * * *$ \\
\hline Internationalization Experience & 0.29 & $2.83 * * *$ \\
\hline Technology intensity & -0.10 & -1.11 \\
\hline Inclusive value & 0.23 & $1.78 *$ \\
\hline \multicolumn{3}{|l|}{ Control Variables } \\
\hline Vertical keiretsu & 0.17 & 0.61 \\
\hline Horizontal keiretsu & -0.28 & -1.20 \\
\hline Firm size & -0.06 & -0.60 \\
\hline Number of observations & & 519 \\
\hline Pseudo $\mathrm{R}^{2}$ & & 0.26 \\
\hline Loglikelihood & & $-266.3 * * *$ \\
\hline$\%$ correctly predicted & & 74 \\
\hline
\end{tabular}

Note: Z-value is asymptotic normally distributed $*=$ significantly different from zero at the 10 percent level, $* *=$ 5 percent level, $* * *=1$ percent level. A choice is correctly predicted if the predicted probability is greater than 0.5 . 
Table 4. Conditional Logit Model of the Choice Between International Plant Configurations

reference state:

\author{
West-bound \\ Asia-bound \\ coefficient \\ t-ratio \\ (asymptotic)
}

Firm and Industry characteristics:

intercept

Product cycle

firm market share 5-10\%

firm market share $10-20 \%$

firm market share > $20 \%$

Japan world market share $>25 \%,<75 \%$

Japan world market share $>75 \%$

Core product

Technology intensity

Configuration-specific variables:

Tariffs

Antidumping \& VERs

Market size

Regional Experience

Control variables:

Firm size

Loose oligopoly

Vertical keiretsu

Horizontal keiretsu

Number of choosers (choices)

Pseudo $\mathrm{R}^{2}$

Loglikelihood

$\%$ correctly predicted

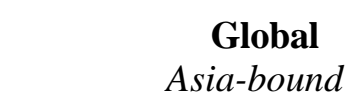

coefficient

(asymptotic)

$\begin{array}{rc}-4.30 & -1.48 \\ -1.39 & -3.23 * * * \\ 0.71 & 1.10 \\ 1.55 & 2.59 * * * \\ -0.20 & -0.29 \\ 1.03 & 1.42 \\ -0.42 & -0.53 \\ 0.28 & 0.52 \\ 0.21 & 1.19 \\ & \\ 0.76 & 1.50 \\ 1.39 & 4.79 * * * \\ 4.58 & 3.51 * * * \\ -0.13 & -0.93 \\ & \\ 0.30 & 1.69 * \\ 0.34 & 0.74 \\ -0.12 & 1.19 \\ 0.06 & 0.13\end{array}$

t-ratio

$$
\begin{aligned}
& -3.63 * * * \\
& -1.17 \\
& 1.60 \\
& 4.00 * * * \\
& 3.60 * * * \\
& 2.54 * * \\
& 2.63 * * * \\
& 2.72 * * * \\
& -1.53 \\
& \\
& 1.50 \\
& 4.79 * * * \\
& 3.51 * * * \\
& -0.93 \\
& \\
& 2.06 * * \\
& 2.43 * * \\
& 0.31 \\
& 0.60
\end{aligned}
$$$$
-0.27
$$

West-bound

Global

coefficient t-ratio

(asymptotic)

$\begin{array}{rl}6.72 & 2.62 * * * \\ -0.92 & -2.55 * * \\ -0.23 & -0.40 \\ -0.68 & -1.42 \\ -2.34 & -3.77 * * * \\ -0.61 & -0.79 \\ -2.43 & -2.83 * * * \\ -1.41 & -2.16 * * \\ 0.51 & 2.58 * * * \\ & \\ 0.76 & 1.50 \\ 1.39 & 4.79 * * * \\ 4.58 & 3.51 * * * \\ -0.13 & -0.93 \\ & \\ -0.77 & -1.79 * \\ -0.27 & -0.53 \\ -0.19 & -0.47\end{array}$

Note: $*=$ significantly different from zero at the 10 percent level, $* *=5$ percent level, $* * *=1$ percent level. For configuration-specific variables of the form $Z_{j s}$, one generic coefficient $\delta$ is estimated. A choice is correctly predicted if the predicted probability is greater than 0.333 . 